\title{
Strategi Pengembangan Klaster UKM Keripik Gadung di Kabupaten Tulungagung
}

\section{The Development Strategy for Cluster Gadung Chips SME'S in Tulungagung Regency, East Java}

\author{
Siti Asmaul Mustaniroh'), Oni Zakiyah2) \& Retno Astuti ${ }^{3)}$ \\ 1,2,3)Jurusan Teknologi Industri Pertanian, Fakultas Teknologi Pertanian, \\ Universitas Brawijaya, Indonesia \\ *Corresponding Author : e-mail: asmaul_m@yahoo.com
}

\begin{abstract}
Abstrak
Tujuan penelitian adalah menentukan strategi pengembangan klaster berdasarkan kinerja dan kualitas produk serta menganalisis elemen dalam kelembagaan klaster industri keripik gadung di Kabupaten Tulungagung. Produk unggulan keripik gadung di Kabupaten Tulungagung saat ini sedang dikembangkan terkait dengan upaya pemerintah dalam meningkatkan ekonomi daerah melalui penerapan konsep One Village One Product (OVOP). Sentra industri keripik gadung di Kecamatan Kalidawir yang masih aktif produksi sejumlah 25 UKM. Permasalahan yang dihadapi UKM dalam mengembangkan usaha yaitu kelembagaan masih cenderung individu sehingga minimnya komunikasi dan kerjasama antar UKM, kurangnya kerjasama dengan Pemerintah, kegiatan pemasaran dan teknologi yang terbatas serta rendahnya kualitas produk. Metode yang digunakan K-means cluster dan FAHP. Hasil penelitian menunjukkan bahwa pengelompokkan UKM keripik gadung berdasarkan kinerja dan kualitas produk menghasilkan 2 klaster. Klaster 1 terdiri dari 11 anggota UKM skala kecil dan klaster 2 terdiri dari 14 anggota UKM skala usaha mikro. Strategi pengembangan klaster 1 yang dapat dilakukan dengan melakukan peningkatan inovasi pada feature produk dan strategi pengembangan klaster 2 melalui peningkatan akses permodalan. Kelembagaan pada klaster industri keripik gadung terdiri dari beberapa pihak yang terlibat di antaranya industri inti, industri pendukung, pemasok, lembaga pendukung dan pembeli. Keberhasilan pengembangan klaster industri keripik gadung sangat bergantung kepada hubungan kerjasama antar kelembagaan.
\end{abstract}

Kata Kunci: klaster, keripik gadung, strategi

\begin{abstract}
The research objective was to determine the cluster development strategy based on product performance and quality and analyze the elements in the institutional cluster of gadung chips in Tulungagung Regency. The superior product of gadung chips in Tulungagung Regency is currently being developed in connection with the government's efforts to improve the regional economy through the application of the One Village One Product (OVOP) concept. The center of the gadung chips industry in Kalidawir Subdistrict, which is still active, produces 25 SMEs. The problems faced by SMEs in developing businesses, individuals, lack of communication and cooperation among SMEs with the Government, limited marketing and technology activities and low product quality. The method used is $K$-means cluster and FAHP. The results showed that the grouping of SMEs gadung chips based on the performance and quality of the products produced 2
\end{abstract}


Mustaniroh, A, S, Zakiyah, 0, \& Astuti, R, Analisis Klaster Industri Keripik Gadung di Kabupaten Tulungagung

clusters. Cluster 1st consists of 11 small-scale members and cluster 2nd consists of 14 micro business scale. Development strategy of cluster 1st by increasing innovation on product features and cluster 2 nd through increased access to capital. The institutions consist of several parties involved including core industries, supporting industries, suppliers, supporting institutions and buyers. The success of the development of the gadung chips industry cluster is highly dependent on inter-institutional cooperation relationships.

\section{Keywords: cluster, gadung chips,strategy}

How to Cite: Mustaniroh, A.S. Zakiyah, O \& Astuti, R. (2019). Analisis Klaster Industri Keripik Gadung di Kabupaten Tulungagung. Jurnal Konsep Bisnis dan Manajemen. 5 (2): 221 - 237 


\section{PENDAHULUAN}

Upaya pemerintah

dalam meningkatkan ekonomi daerah melalui penerapan konsep One Village One Product (OVOP) yang melibatkan usaha kecil menengah (UKM) dan sentra industri potensial di setiap daerah. Konsep OVOP merupakan gerakan revitalisasi daerah dan salah satu pendekatan menuju klasterisasi produk unggulan agar dapat berkembang dan mengakses pasar secara luas dengan mengutamakan produk unik disetiap daerah (Schumann, 2016). Penerapan konsep OVOP bertujuan meningkatkan perekonomian wilayah yang berorientasi komunitas dengan memanfaatkan pengetahuan lokal dan sumber daya setempat (Kinyahui et al., 2013).

Kabupaten Tulungagung salah satu daerah pegunungan di Jawa Timur yang memiliki potensi tanaman umbi gadung (Djafar, 2013). Umbi gadung diolah menjadi keripik gadung yang dikembangkan sebagai produk unggulan daerah Tulungagung. Pendekatan OVOP oleh pemerintah untuk mengangkat potensi daerah yang belum terekspose secara optimal namun memiliki peluang dan kekuatan ekonomi rakyat (Nguyen Thi, 2013). Sentra industri pengolahan produk unggulan keripik gadung terletak di Dusun Ngampel Kecamatan Kalidawir.
Luas wilayah Kecamatan Kalidawir sebesar $97.81 \mathrm{~km}^{2}$ dengan jumlah penduduk \pm 1.559 orang (BPS, 2017).

Produsen keripik gadung yang masih aktif produksi sejumlah 25 UKM. Selama ini usaha keripik gadung di Kecamatan Kalidawir memiliki beberapa kendala dari segi kinerja dan kualitas. Kendala kinerja dan kualitas produk di antaranya kelembagaan masih cenderung individu, belum ada asosiasi dan kerjasama dengan Pemerintah, kegiatan pemasaran yang terbatas serta rendahnya kualitas produk. Pengukuran kinerja dapat dilihat dari segi keuangan (modal, laba, pendapatan) atau kegiatan non finansial (pertumbuhan penjualan, tenaga kerja) (Maduekwe dan Kamala 2016). Berdasarkan permasalahan tersebut maka diperlukan klaster untuk meningkatkan daya saing industri keripik gadung.

Klaster ditingkat daerah ditujukan untuk meningkatan daya saing yang saling berhubungan satu sama lain dengan beberapa pihak yang mendukung dalam kelancaran kegiatan industri (Porter, 1998). Daya saing suatu UMKM dibentuk berdasarkan kondisi lingkungan usaha, kemampuan usaha, kebijakan dan infrastruktur, riset dan teknologi, dukungan finansial dan kemitraan dan kinerja (Syafitri dkk, 2017). Perkembangan regional klaster salah satu 
Mustaniroh, A, S, Zakiyah, O, \& Astuti, R, Analisis Klaster Industri Keripik Gadung di Kabupaten Tulungagung

elemen penting dari kebijakan means clustering dan Fuzzy Analytical pengembangan potensi inovatif dari setiap Hierarchy Process (FAHP) serta mengetahui wilayah (Arzhakov dan Silnov, 2016). elemen-elemen yang tergabung dalam Keuntungan klaster memungkinkan kelembagaan klaster industri keripik gadung anggota menjadi lebih produktif dan inovatif (Bogdanova dan Lemetti, 2011). Strategi usaha yang komprehensif diperlukan dengan melibatkan relasional antara pendekatan aliansi strategik dan klaster industri (Clarke dan Turner, 2004).

Penelitian Sugiato dkk (2010), menghasilkan model strategi pengembangkan klaster industri dengan aktor yang paling berperan dalam pengembangan klaster adalah Lembaga Penukung diikuti pemerintah dan industri. Strategi pengembangan klaster yang dapat dilakukan melalui inisiatif inovasi dan teknologi dengan area pengetahuan. Penelitian Doronina et al., (2016), menunjukkan pembentukan klaster menuntut kebijakan negara aktif untuk meningkatkan persaingan dan konsentrasi produksi dibidang agraria, yang dapat meningkatkan inovatif, diversifikasi struktur ekonomi dan memberikan efek sinergis. Namun demikian beberapa penelitian terdahulu belum terkait dengan analisis strategi pengembangan serta kelembagaan klaster untuk mendukung pengembangan usaha.

Penelitian ini dirancang untuk menghasilkan strategi pengembangan klaster UKM keripik gadung dengan metode $K$ -

\section{METODE PENELITIAN}

Penelitian dilakukan di UKM keripik gadung Kecamatan Kalidawir dengan teknik pengambilan sampel jenis sampling jenuh (saturation sampling). Responden terdiri dari 25 pihak UKM, 30 konsumen dan 3 pakar ahli. Metode yang analisis $k$-means clustering dan FAHP. Penentuan jumlah klaster dilakukan terlebih dahulu menggunakan metode elbow. Tools yang digunakan dalam analisis klaster adalah software Rstudio dan SPSS 17.0.

Tabel 1. Variabel Penelitian

\begin{tabular}{|c|c|}
\hline Simbol & Variabel \\
\hline \multicolumn{2}{|c|}{ Kinerja UKM } \\
\hline $\mathrm{X}_{1}$ & Lama usaha (tahun) \\
\hline $\mathrm{X}_{2}$ & Kapasitas produksi (kg/bulan) \\
\hline $\mathrm{X}_{3}$ & Jumlah tenaga kerja (orang) \\
\hline $\mathrm{X}_{4}$ & Nilai investasi awal (Rp) \\
\hline $\mathrm{X}_{5}$ & Rata-rata penjualan (kg/bulan) \\
\hline $\mathrm{X} 6$ & Rata-rata pendapatan (Rp/bulan) \\
\hline \multicolumn{2}{|c|}{ Kualitas produk } \\
\hline $\mathrm{Y}_{1}$ & Kinerja (Performance) \\
\hline $\mathrm{Y}_{2}$ & Keandalan (Reliability) \\
\hline $\mathrm{Y}_{3}$ & $\begin{array}{l}\text { Keistimewaan } \\
\text { (Feature) }\end{array}$ \\
\hline $\mathrm{Y}_{4}$ & Daya tahan (Durability) \\
\hline
\end{tabular}

Sumber: Garvin 1987

HASIL DAN PEMBAHASAN

Gambaran Umum UKM Keripik Gadung di Kecamatan Kalidawir 
Kecamatan Kalidawir merupakan reliability 0.626, feature 0.881, dan sentra produksi keripik gadung karena durability 0.663. Hal ini menunjukkan lokasi dekat dengan sumber bahan baku bahwa variabel memiliki nilai Alpha dan tersedianya jumlah tenaga kerja. Cronbach $>0.600$, berarti keempat Bisnis keripik gadung merupakan bisnis instrumen dinyatakan reliabel. turunan, sekitar 5,8\% masyarakat mata pencaharian sebagai produsen keripik gadung. Jumlah UKM keripik gadung yang masih aktif produksi sekitar 25 UKM yang berstatus kepemilikan perseorangan. Kegiatan produksi keripik gadung dilakukan pada musim kemarau sekitar bulan Juni-Agustus karena sifat bahan baku yang musiman (Kumoro et al., 2014). Kapasitas produksi yang dihasilkan UKM keripik gadung mencapai sekitar $5.416 \mathrm{~kg}$ per bulan. Produk yang dihasilkan berupa keripik gadung mentah atau belum digoreng.

Hasil uji validitas kuesioner untuk penilaian kualitas terdiri dari indikator performance, reliability, feature dan durability dengan nilai rhitung (Corrected Item-Total Correlation) $>r_{\text {tabel }}$ sebesar 0.422 sehingga dapat dikatakan valid. Hasil uji validitas menunjukkan bahwa seluruh pernyataan yang dibuat dinilai layak dan dapat digunakan untuk keperluan penelitian (Haynes et al., 2017). Hasil koefisien reliabilitas menunjukkan $\mathrm{r}_{\mathrm{alpha}}$ performance sebesar 0.642,

\section{Analisis Klaster}

Analisis klaster UKM keripik gadung menggunakan metode $K$-means clustering. Penentuan jumlah klaster dilakukan 4 kali percobaan clustering dengan asumsi 4 macam skala usaha yaitu usaha mikro, kecil, menengah dan besar. Hasil perhitungan nilai SSE pada tiap klaster dapat dilihat pada Tabel 2.

Tabel 2. Hasil Uji SSE
\begin{tabular}{|l|l|l|}
\hline Jumlah Klaster & SSE & Selisih \\
\hline 1 & 25.384375 & \\
\hline 2 & 19.203680 & $\mathbf{6 . 1 8 0 6 9 5}$ \\
\hline 3 & 15.792971 & 3.410709 \\
\hline 4 & 13.542507 & 2.250464 \\
\hline
\end{tabular}

Tabel 2 diketahui klaster yang mengalami penurunan selisih terbesar terletak pada klaster 2 dan 3, yaitu 6.180695 dan 3.410709 sehingga dilakukan perhitungan nilai withim sum of square by cluster dari klaster 2 dan 3 . Nilai withim sum of square by cluster dari $\mathrm{k}=2$ nilainya sebesar $20.5 \%$ sedangkan pada $\mathrm{k}=3$ nilainya sebesar $37.3 \%$. Penentuan jumlah klaster tergantung dari selisih SSE terbesar dan nilai withim sum of square by cluster yang terkecil. 
Tabel 3. Karakteristik UKM Masing-masing Klaster

\begin{tabular}{|c|c|c|c|c|c|c|}
\hline \multirow[t]{2}{*}{ Karakteristik } & \multicolumn{3}{|c|}{ Klaster 1 (11 UKM) } & \multicolumn{3}{|c|}{ Klaster 2 (14 UKM) } \\
\hline & Pusat Klaster & Minimal & Maksimal & Pusat Klaster & Minimal & Maksimal \\
\hline \multicolumn{7}{|l|}{ Kinerja UKM } \\
\hline Lama Usaha & 16 & 6 & 27 & 12 & 3 & 20 \\
\hline Kapasitas produksi & 7000 & 6000 & 8000 & 4171 & 2400 & 6000 \\
\hline Tenaga Kerja & 11 & 5 & 15 & 5 & 3 & 9 \\
\hline Nilai investasi awal & 51.818 .181 & 50.500 .000 & 53.000 .000 & 29.017 .857 & 21.500 .000 & 32.500 .000 \\
\hline Rata-rata penjualan & 588 & 500 & 660 & 327 & 200 & 500 \\
\hline Rata-rata pendapatan & 28.000 .000 & 24.000 .000 & 32.000 .000 & 16.285 .714 & 12.000 .000 & 24.000 .000 \\
\hline \multicolumn{7}{|l|}{ Kualitas Produk } \\
\hline Performance & 4.03 & 2.77 & 4.61 & 3.78 & 3.35 & 4.24 \\
\hline Reliability & 2.80 & 2.21 & 3.48 & 2.62 & 2.10 & 3.22 \\
\hline Feature & 2.58 & 1.77 & 3.32 & 2.34 & 1.72 & 2.77 \\
\hline Durability & 4.22 & 3.75 & 4.75 & 3.96 & 2.67 & 4.55 \\
\hline
\end{tabular}

Menurut Calinski dan Harabasz (1974), semakin kecil nilai within sum of squares maka cluster yang terbentuk semakin baik. Hal tersebut menunjukkan bahwa nilai SSE pada klaster 2 lebih optimal sehingga penelitian ini menggunakan 2 clustering. Hasil pengelompokkan UKM menggunakan metode K-means clustering dapat dilihat pada Tabel 3.

Klaster 1 terdiri dari 11 UKM tergolong skala usaha kecil dan klaster 2 terdiri dari 14 UKM tergolong skala usaha mikro. Perbedaan skala usaha didasarkan pada nilai investasi dan rata-rata penjualan tahunan. Klaster 1 memiliki nilai investasi rata-rata $\mathrm{Rp51.818.181}$ dan pendapatan pertahun berkisar Rp336.000.000. Klaster 2 rata-rata nilai investasi awal sebesar Rp29.017.857 dan penjualan berkisar Rp144.000.000.
Klaster 1 memiliki karakteristik waktu operasional yang lebih lama dibandingkan klaster 2. Rata-rata lama operasi usaha keripik gadung klaster 1 sekitar 16 tahun sedangkan klaster 2 sekitar 12 tahun. UMK klaster 1 memiliki pengalaman lebih lama dalam menjalankan bisnis keripik gadung. Lama usaha berpengaruh terhadap pengalaman dari suatu usaha karena dapat mempengaruhi keberhasilan dari usaha tersebut (Omole dan Omolayo, 2013).

Tenaga kerja yang digunakan sebagian besar dari tetangga sekitar. Hubungan antara pertumbuhan UKM dan produktivitas tenaga kerja perusahaan dapat berhubungan positif dan negatif tergantung pada efek yang dimiliki terhadap pertumbuhan usaha (Yee et al., 2010). Pengaruh pertumbuhan terhadap kinerja perusahaan mempertimbangkan 
profitabilitas keuangan, diukur dengan rasio antara hasil operasional dan total aset sebagai ukuran kinerja perusahaan (Goddard et al., 2005).

Anggota klaster 1 dan 2 memiliki kapasitas produksi yang relatif tetap karena UKM menggunakan pemasok bahan baku dan pasar yang tetap. Kapasitas salah satu tolak ukur yang penting dari suatu perusahaan (Vorotilin, 2009). Kapasitas produksi menentukan volume produk yang dihasilkan oleh perusahaan dalam suatu periode tertentu dengan menggunakan sumber daya (Ardalan et al., 1993).

Dimensi kualitas produk menjadi pertimbangan dalam mengelompokkan UKM. Pada Tabel 3 dijelaskan bahwa nilai dimensi performance klaster 1 lebih mendekati skala 4 sesuai dengan standar SNI 01-4302-1996 tentang warna keripik gadung kuning keputih-putihan, aroma khas gadung dan tekstur normal sedikit kasar. Menurut Beverly et al. (2002), kinerja mengacu pada produk inti yang mencakup atribut produk dan aspek kinerja. Peningkatan kinerja produk keripik dapat dinilai dari berbagai feature warna, ukuran, bentuk dan tekstur (Marique et al., 2007). Dimensi reliability klaster 1 dan 2 2017). terletak pada skala 2 dimana nilai 2013).

reliability tidak sesuai dengan standar SNI karena terdapat kotoran pada produk, keripik gadung mudah rapuh atau hancur, dan kemasan tidak tertutup rapat. Dimensi keandalan (reliability) terkait dengan peluang suatu produk bebas dari kegagalan saat menjalankan fungsinya (Asghari et al., 2014). Kebersihan dan kualitas produk dapat dijaga dengan menggunakan kemasan yang tepat serta sebagai media promosi yang dapat menarik minat pembeli (Dobermann et al.,

Dimensi feature klaster 1 dan 2 mendekati skala 2 berarti feature keripik gadung menurut responden tidak sesuai dari segi kemasan yang mudah sobek dan kurang menarik, kemasan tidak bersifat informatif dan tidak ada variasi bentuk produk. Dimensi durability klaster 1 terletak pada skala 4 dan klaster 2 mendekati klaster 4 menunjukkan nilai durability sesuai dengan umur simpan produk sekitar 1-1,5 tahun dan produk tidak berjamur. Keripik mentah atau setengah jadi memiliki masa simpan yang lebih lama dibandingkan keripik yang sudah digoreng dikarenakan keripik yang sudah digoreng memiliki kandungan lemak yang tinggi (Martina dan Asrina, 
Analisis statistik uji independen sampel t-test pada variabel kinerja klaster 1 dan 2 (kapasitas produksi, jumlah tenaga kerja, nilai investasi, penjualan produk, dan pendapatan usaha) sebesar 0.00 atau $<0.05$ yaitu nilai kinerja klaster 1 dan 2 terdapat perbedaan yang signifikan. Hasil uji sampel t-test variabel kualitas produk pada dimensi performance dan feature sebesar 0.15 , dimensi reliability sebesar 0.26 serta dimensi durability sebesar 0.11 menunjukkan nilai >0.05 yaitu kualitas produk klaster 1 dan 2 tidak ada perbedaan yang signifikan.

\section{Kelembagaan Klaster Industri}

UKM keripik gadung di Kecamatan Kalidawir memiliki peluang untuk dikembangkan untuk meningkatkan perekonomian daerah, hal ini didukung adanya inisiasi dari pemerintah Provinsi Jawa Timur melalui konsep OVOP. Pengembangan kelembagaan di tingkat lokal dapat dilakukan dengan sistem jejaring kerjasama yang setara dan saling menguntungkan. UKM keripik gadung memiliki keterkaitan dengan beberapa pihak yang mendukung dalam kelancaran kegiatan industri. Pihak-pihak tersebut terdiri dari industri inti dan steakholder (pemasok, industri pendukung, lembaga pendukung dan pembeli) yang mendukung keberlangsungan klaster keripik gadung. Keberhasilan pengembangan klaster industri sangat bergantung kepada hubungan kerjasama antar kelembagaan (Bembenek, 2015). Keterkaitan klaster 1 dan 2 dengan beberapa pihak pada kelembagaan klaster industri dapat dilihat pada Gambar 1.

\section{Pemasok}

Pemasok memiliki peranan penting dalam klaster industri sebagai penyedia bahan baku yang dibutuhkan industri. Rata-rata klaster 1 dan 2 memiliki supplier yang berasal dari Tulungagung, Trenggalek, Blitar, Madiun, Ponorogo dan Madura. Supplier yang berasal dari Blitar merupakan supplier yang mampu memenuhi kebutuhan bahan baku untuk klaster 1 sedangkan supplier dari Tulungagung dan Trenggalek mampu memenuhi kebutuhan bahan baku untuk klaster 2. Supplier dari Madiun, Ponorogo dan Madura memasok bahan baku ke UKM apabila supplier Blitar, Tulungagung dan Trenggalek tidak mampu memenuhi permintaan.

Pada klaster 1 terdapat salah satu anggota UKM pemilik Bu Ponirah yang mengkoordinir untuk pembelian bahan baku, dari 11 UKM terdapat 9 UKM yang mengambil bahan baku di $\mathrm{Bu}$ Ponirah dengan tujuan mempermudah UKM memperoleh bahan baku serta dapat mengurangi biaya transportasi. Menjalin kemitraan dengan pemasok secara 
signifikan dapat meningkatkan kinerja produksi, distribusi dan pelayanan dapat perusahaan (Zucchella dan Siano, 2014). berjalan lancar. Bisnis yang berlokasi di Pemasok menyediakan bahan baku dan dalam klaster industri akan mengurangi bahan pendukung dengan jumlah, mutu biaya transaksi dengan menggunakan dan harga yang sesuai sehingga proses

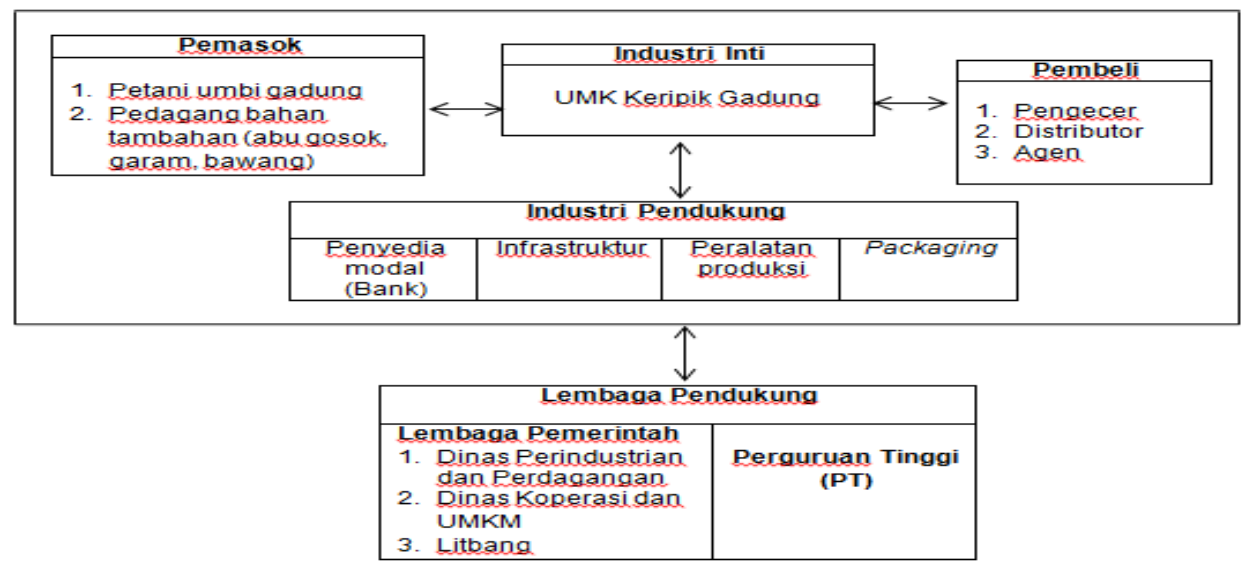

Gambar 1. Kelembagaan Klaster UMK Keripik Gadung

Pemasok lokal daripada membeli dan pasokan lebih mudah terbangun bahan baku dari pemasok jarak jauh ketika proses antar perusahaan dan (Isbasoiu, 2007).

\section{Industri Inti}

Industri inti berperan dalam melakukan kegiatan produksi, koordinasi antar kelembagaan dan menjalin kerjasama antar elemen. Klaster 1 terdiri dari 11 UKM dengan rata-rata lama beroperasi 16 tahun. Pada klaster 2 terdiri dari 14 UKM dengan rata-rata lama usaha 12 tahun. Pada sisi kelembagaan industri inti dan kelembagaan pendukungnya sebagian besar masih berjalan individu sehingga interaksi kelembagaan di antara pelaku tidak terbangun dengan baik. Peningkatan kinerja perusahaan individual hubungan dalam rantai secara aktif dikelola (Mentzer et al., 2001).

Industri inti berhubungan dengan industri pemasok dalam penyedia bahan baku, industri pendukung sebagai penyedia mesin dan peralatan, pembiayaan dan infrastruktur. Industri inti berhubungan dengan lembaga pendukung dalam menjaga stabilitas ekonomi, melakukan pembinaan, pelatihan pengembangan UKM dan membangun infrastruktur yang dibutuhkan UKM. Konsentralisasi industri pada sebuah lokasi dapat berdampak penghematan biaya bagi perusahaan dalam klaster 
(Todtling dan Trippl, 2008). Penghematan bersumber dari adanya pemasok khusus, penambahan tenaga kerja terlatih dan meningkatnya kecenderungan transfer informasi dan teknologi antar UKM (Siahaan, 2016).

\section{Industri Pendukung}

Keberadaan industri pendukung sangat penting karena memiliki interaksi dengan industri inti. Industri pendukung pada klaster industri keripik gadung terdiri dari:

\section{Pembiayaan (Bank)}

UKM keripik gadung membutuhkan permodalan dalam melakukan kegiatan operasional, baik untuk modal kerja maupun untuk investasi. Pada klaster 1 terdapat 4 UKM yang mendapatkan bantuan permodalan untuk usaha sedangkan klaster 2 belum ada yang mendapatkan bantuan modal dikarenakan pelaku usaha klaster 2 rata-rata tidak mengetahui tata acara pengajuan kredit usaha ke perbankan sehingga banyak pelaku usaha yang enggan untuk mengajukan kredit usaha ke bank serta sebagian besar UKM tidak menginginkan risiko dari bunga bank. Industri pendukung berperan meningkatkan efisiensi dan sinergi dalam klaster. Sinergi dan efisiensi dapat tercipta terutama dalam transaction cost, sharing teknologi, informasi maupun skill tertentu yang dapat dimanfaatkan oleh industri atau perusahaan lainnya (Liu et al., 2016).

\section{Infrastruktur}

Sentra keripik gadung terletak di Dusun Ngampel Kecamatan Kalidawir yang sebagian wilayahnya adalah pegunungan. Kondisi daerah Kecamatan Kalidawir khususnya di Dusun Ngampel, selama ini tidak memiliki masalah dan hambatan dalam hal infrastruktur terkait kondisi transportasi, listrik air maupun jaringan komunikasi. Kondisi jalan di Kecamatan Kalidawir sudah di aspal sehingga memudahkan untuk kegiatan transportasi. Berdasarkan dokumen Tataran Transportasi Perkotaan (2015), Kabupaten Tulungagung dilayani oleh 2 moda transportasi yaitu jalan dan kereta api. Sarana jalan menuju tempat-tempat penting dan daerah tujuan utama hampir seluruhnya diperkeras aspal, yakni 95\% dengan perkerasan aspal dan 5\% dengan perkerasan kerikil dan makadam.

Kegiatan produksi keripik gadung juga membutuhkan jumlah pasokan air untuk kegiatan produksi. Unit air yang digunakan UKM berasal dari air sumur dan PDAM. Pemenuhan kebutuhan pasokan air di Dusun Ngampel selama ini sudah terpenuhi dengan baik sehingga UKM dapat menjalankan kegiatan operasional dengan lancar. Persediaan energi listrik untuk produksi keripik gadung di 
Kecamatan Kalidawir juga mendapat kemudahan dalam mendapatkan pasokan. Infrastruktur dibutuhkan pada klaster industri untuk menunjang kegiatan operasional (Rijanto, 2017).

\section{Peralatan produksi dan Packaging}

Ketersediaan peralatan dibutuhkan dalam menunjang kegiatan produksi keripik gadung di Kecamatan Kalidawir. Peralatan yang digunakan UKM tergolong tradisional dan manual yang sepenuhnya menggunakan tenaga manusia. Mesin dan peralatan sebagian diperoleh di pedagang yang ada di pasar Kalidawir dan untuk hydraulic press UKM memesan ke industri khusus yang menjual hydraulic press. Hubungan interaksi antara industri inti dengan penyedia peralatan produksi tidak dilakukan secara intensif karena peralatan yang digunakan memiliki masa pakai yang cukup lama sekitar 2-2.5 tahun dan UKM melakukan interaksi dengan penyedia peralatan apabila alat yang digunakan sudah aus dan harus di ganti.

$$
\text { Industri pendukung yang }
$$

menyediakan bahan pendukung seperti kemasan sangat dibutuhkan dalam proses packaging keripik gadung. Kemasan yang digunakan adalah kemasan berbahan plastik polyethylene (PE) dengan ukuran 115 kg. Kebutuhan bahan kemasan selama ini sudah dapat terpenuhi di toko khusus kemasan yang ada di Kalidawir. Hubungan interaksi antara industri inti dengan penyedia kemasan dilakukan secara intensif. UKM membeli bahan kemasan tiap 2 bulan sekali.

\section{Lembaga Pendukung}

Perkembangan UKM keripik gadung di suatu daerah tidak dapat lepas dari peran pemerintah. Lembaga pendukung berasal dari Dinas Pemerintah, Litbang dan Perguruan Tinggi (PT). Peran Pemerintah terhadap UKM Keripik Gadung di Kecamatan Kalidawir adalah melakukan pembinaan dan pelatihan BIMTEK (Bimbingan Teknis) pengembangan usaha, memberikan akses bantuan pemodalan, dan memberikan informasi terkait bazar atau pameran kewirausahaan yang diadakan oleh Pemerintah Kabupaten Tulungagung. Pemerintah masih terbatas dalam memberi dukungan kepada para pelaku UMKM.

Peran Pemerintah selama ini, masih belum merata dari 25 UKM hanya 5\% yang mendapatkan bimbingan dan bantuan dari Pemerintah. Kendala yang di hadapi oleh Dinas Perindustrian dan Koperasi Kabupaten Tulungagung adalah kurangnya informasi dari kelompok serta jumlah penyuluh lapang dari pusat ke UKM masih sedikit, sehingga proses pengajuan proposal oleh kelompok UKM serta 
pendampingan oleh penyuluh masih kurang tersebar secara merata. Lembaga penelitian dan pengembangan (Litbang) dan perguruan tinggi (PT) memainkan peran yang sangat penting terkait riset pengembangan klaster keripik gadung dalam hal proses produksi, inovasi dan teknologi akan tetapi, kegiatan pengembangan inovasi dan teknologi yang dilakukan lembaga pendukung untuk UKM selama ini relatif rendah.

Lembaga pendukung memiliki hubungan dengan industri inti dan steakholder dalam pengembangan usaha. Hubungan tersebut berkaitan dengan bantuan permodalan, pemasaran serta mendukung dalam menjalin kerasama dengan Perguruan Tinggi dalam hal inovasi dan transfer teknologi. Tanpa pemerintah intervensi untuk memfasilitasi pembentukan dan pemeliharaan kelompok tidak akan ada karena secara umum perusahaan tidak menyadari manfaat dari strategi kooperatif (Haddoud et al., 2017).

\section{Pembeli}

Pada klaster 1 kegiatan pemasaran keripik gadung sebagian besar dilakukan melalui distributor, pengecer dan agen. Aliran informasi yang berlangsung antara UKM dengan distributor terkait jumlah produk yang dipasarkan. Klaster 1 menjual produk melalui retailer. Sedangkan klaster 2 dilakukan sendiri oleh pihak UKM tanpa melalui retailer, karena wilayah pemasaran keripik gadung klaster 2 hanya di Jawa Timur dengan jumlah wilayah pemasaran yang lebih sedikit dibanding klaster 1. Hasil penjualan yang terbanyak dari UKM berasal dari distributor dan agen dengan rata-rata pembelian produk sejumlah $30 \mathrm{~kg}$ tiap pembelian, sedangkan pembeli eceran dari keripik gadung ratarata terjual sebanyak $5 \mathrm{~kg}$ tiap pembelian. Hal ini menunjukkan bahwa sistem pembelian yang sangat prospek untuk produksi keripik gadung berasal dari distributor.

$\begin{array}{crrrr}\text { Klaster } & 1 & \text { dan } & 2 & \text { berupaya } \\ \text { meningkatkan } & \text { penjualan } & \text { melalui }\end{array}$
penerapan relationship marketing melalui hubungan komunikasi yang baik dengan pelanggan sehingga tidak terjadi kesalahan dalam pemesanan jumlah produk dan memberikan potongan harga tertentu bagi pelanggan. Penerapan relationship marketing digunakan oleh perusahaan untuk mempertahankan konsumen yang sudah menjadi pelanggannya, dan untuk memperoleh konsumen yang baru (Hurley dan Hult, 1998).

\section{Analisis Prioritas Strategi Pengembangan Klaster}

Analisis strategi pengembangan klaster dengan metode FAHP melibatkan 3 pakar, yaitu anggota UKM skala kecil dan mikro, Disperindag dan Dinas Koperasi. Permasalahan digambarkan dan diuraikan 
menjadi beberapa unsur terdiri dari level, kriteria dan alternatif yang disusun menjadi struktur hirarki (Mikhailov dan Tsvetinov, 2004). Kriteria pemilihan strategi klaster 1 dan 2 disesuiakan dengan kondisi klaster. Hasil analisis hirarki klaster 1 dapat dilihat pada Gambar 1.

\section{Klaster 1}

Bobot prioritas faktor utama klaster 1 adalah kualitas produk sebesar 0.529 . Kriteria bobot tertinggi terletak pada feature produk dengan nilai 0.226 . Alternatif strategi yang diusulkan untuk pengembangan klaster 1 melalui

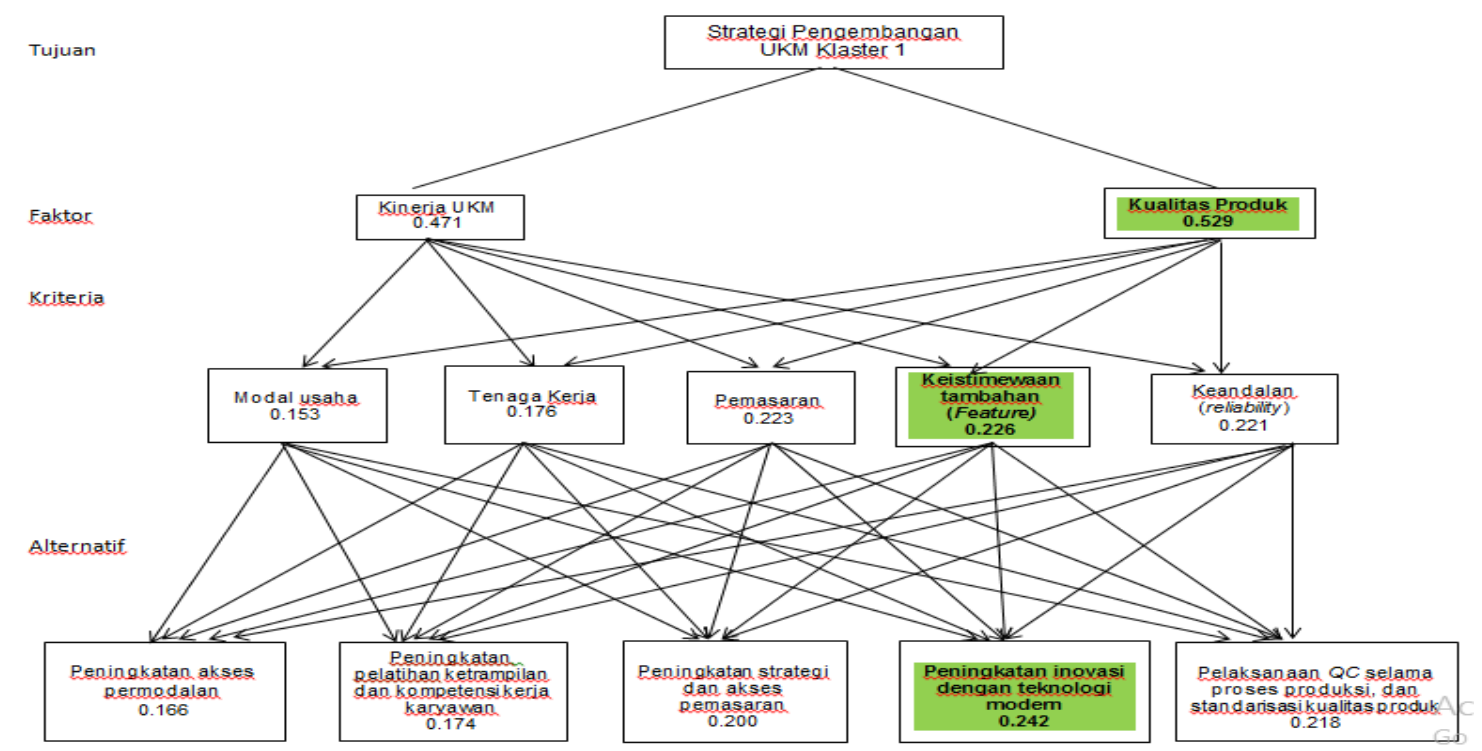

Gambar 1. Hirarki Klaster 1

sehingga produk keripik gadung

melalui peningkatan inovasi produk dengan teknologi modern dengan nilai 0.242 .

Strategi pengembangan usaha yang dapat dilakukan klaster 1 adalah melakukan inovasi feature produk dengan menambah variasi bentuk dan inovasi kemasan. Umumnya keripik gadung yang dijual berbentuk bulat lonjong dan dikemas menggunakan plastik polyethyline (PE) agak transparan, tipis sehingga mudah sobek, produk diikat dengan tali terkesan kurang menarik dan tidak ada keunikan yang membedakan dengan produk UKM lainnya, dengan menggunaan kemasan polyprohylene (PP) dapat mengurangi jumlah kerusakan pada kemasan karena plastik bahan PP memiliki sifat lebih kuat, tidak mudah sobek, tahan panas, warna kemasan jernih dan tahan temperatur tinggi.

Penambahan variasi bentuk keripik seperti bentuk persegi memanjang dan bergelombang dapat memberikan kesan berbeda dengan produk keripik gadung 
lainnya sehingga dapat menambah daya tarik konsumen. Pencantuman label pada kemasan juga perlu dilakukan karena label

produk memberikan informasi kepada konsumen terkait merek, No. PIRT, berat netto, tanggal kadaluwarsa, dan komposisi bahan. Penggunaan teknologi modern mesin perajang dan mesin pengemas handsealer dibutuhkan untuk meningkatkan kapasitas produksi dengan tujuan efisiensi dan efektivitas produk agar produk yang dihasilkan berkualitas.

Feature produk identik dengan sesuatu yang unik sehingga menjadi

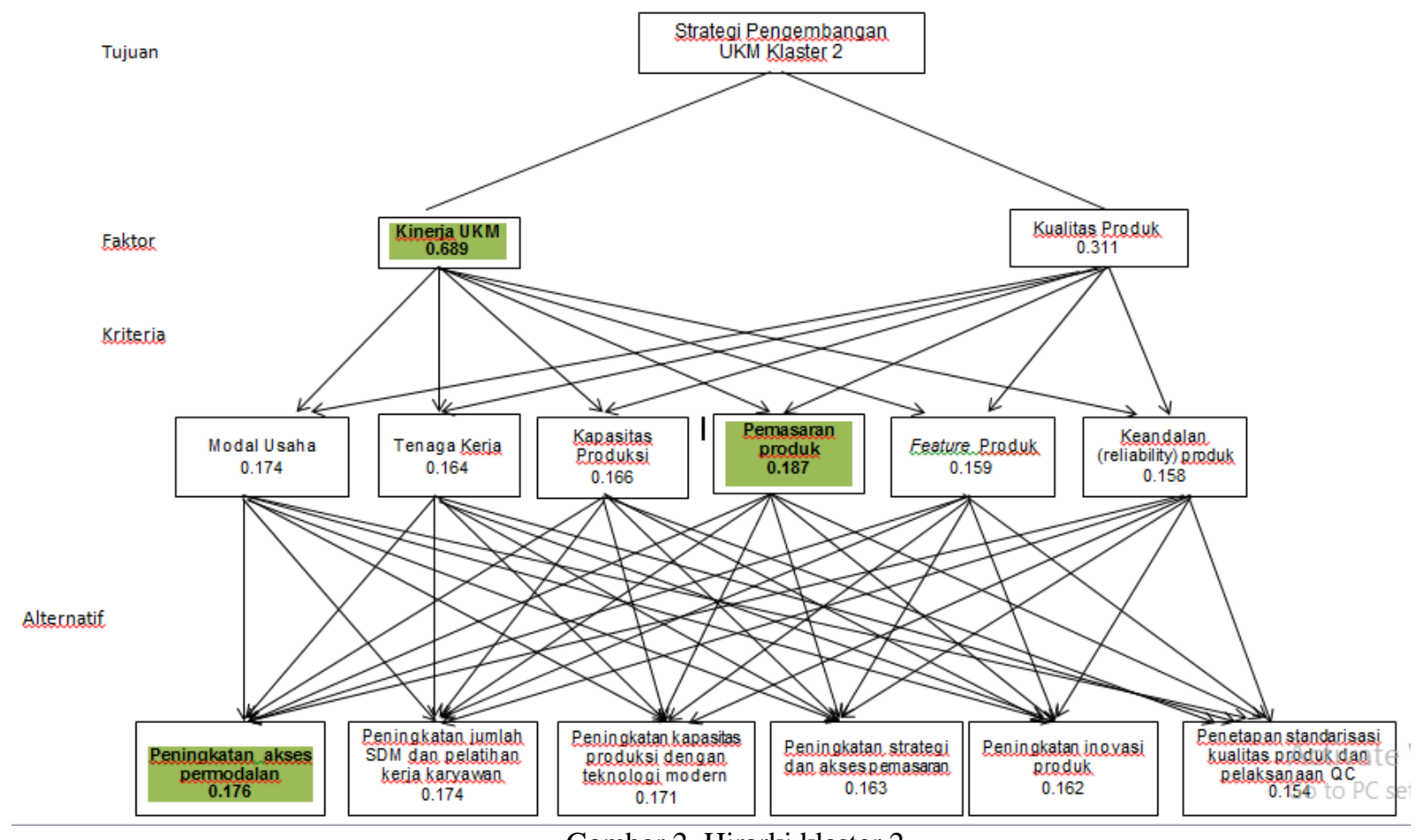

Gambar 2. Hirarki klaster 2

keistimewaan suatu produk. Feature produk yang unggul membuat produk bersaing dengan produk lainnya karena memiliki daya tarik tersendiri untuk konsumen (Nad et al., 2012). Inovasi akan menciptakan berbagai desain produk sehingga dapat meningkatkan alternatif pilihan dan manfaat yang berdampak pada peningkatan kualitas. Peningkatan inovasi membutuhkan teknologi modern karena mempengaruhi kecepatan produktivitas usaha (Hurley dan Hult, 1998).

\section{Klaster 2}

Penyusunan hirarki klaster 2 dapat dilihat pada Gambar 2. Bobot prioritas faktor utama klaster 2 adalah kinerja UKM sebesar 0.689. Kriteria tertinggi adalah pemasaran sebesar 0.187. Alternatif strategi yang diusulkan untuk pengembangan klaster 2 adalah peningkatan akses permodalan dengan bobot 0.176 .

Strategi pengembangan usaha yang dapat dilakukan klaster 2 adalah meningkatkan akses permodalan karena 
modal usaha yang digunakan berasal dari modal pribadi yang terbatas. Ketidakefektifan pada penggunaan modal akan menimbulkan turunnya tingkat profitabilitas yang diperoleh perusahaan (Karanja et al., 2016). Usaha Mikro, Kecil dan Menengah (UMKM) sering kali dihubungkan dengan modal yang terbatas, yang dimiliki seseorang atau sekelompok dalam menjalankan sebuah usaha (Petkovic et al., 2016).

UKM klaster 2 dalam meningkatkan akses pemodalan dapat dilakukan melalui kerjasama dengan Pemerintah atau instansi lain (Bank). Ketersediaan modal yang cukup dapat meningkatkan pemasaran, kapasitas produksi, pembelian mesin dan teknologi modern, melakukan kegiatan pelatihan kerja untuk karyawan serta memperbaiki kualitas produk,. Pemberian pinjaman modal sangat berguna untuk meminimalisir UKM yang tidak berkembang karena kekurangan modal (Danovi dan Apoga, 2015). Penguatan pemodalan dapat memanfaatkan keberpihakan Pemerintah berupa penyedia bantuan dan ketersediaan dana (Singgih, 2007).

\section{SIMPULAN}

Analisis klaster UKM keripik gadung di Kecamatan Kalidawir berdasarkan kinerja dan kualitas produk menggunakan metode K-means clustering menghasilkan 2 klaster, klaster 1 tergolong skala usaha kecil dengan jumlah 11 UKM. Klaster 2 tergolong skala usaha mikro sejumlah 14 UKM. Alternatif prioritas strategi pengembangan klaster 1 melalui peningkatan inovasi feature produk dan klaster 2 melalui peningkatan akses permodalan dan membangun kerjasama dengan Pemerintah serta instansi terkait.

Kelembagaan klaster industri keripik gadung terdapat elemen atau pihak yang mendukung dalam meningkatkan daya saing usaha Industri inti yaitu UKM keripik gadung sebagai produsen. Industri pendukung selaku penyedia modal (Bank), infrastruktur, industri mesin dan peralatan serta packaging. Lembaga pendukung sebagai fasilitator dan Pembina UKM keripik gadung. Peningkatan daya saing usaha keripik gadung perlu dilakukan kerjasama secara integrasi antar elemen atau pihak agar UKM mampu bersaing di pasar yang lebih luas.

\section{DAFTAR PUSTAKA}

Ardalan, A., Pope, A.J \& Hammesfahr, J. (1993). Strategic Planning for Production Capacity. International Journal of Operations \& Production Management. 13 (5), 41 - 53.

Arzhakov, A.V., Silnov, D.S. (2016). New approach to designing an educational automated test generation system based on text analysis. ARPN Journal of Engineering and Applied Sciences 11(5), 2993-2997 
Asghari, M., Jusoh, A and Kianpour, K. (2014). Environmentally Friendly As A New Dimension Of Product Quality. International Journal of Quality \& Reliability Management 31(5), 547-565.

Bembenek, B. (2015). The Sustainable Development of An Industrial Cluster In The Context of Corporate Social Responsibility - A New Challenge For Cluster Management. European Scientific Journal Vol.1 ISSN: 1857 - 7881.

Beverly, K.K., Diane, M. Strong, dan Richard, Y.W. (2002). Information Quality Benchmarks: Product and Service Performance. Journal Communications of The ACM 45 (4).

Bogdanova, O \& Lemetti, J. (2011). Methodical Aspects of Cluster Formation In The Agrarian Sector of The Regional Economy. Journal Economic Researches 5(11), 4-12.

Calinski, T.\& Harabasz, J. (1974). A Dendrite Method for Cluster Analysis: Communications in Statistics. Journal Theory and Methods, 3, 1-27.

Djafar, Z. R. 2013. Limestone Soil Potential For Planting Secondary Crops. Jurnal Lahan Suboptimal 2(1), 58-67.

Donavi, A dan Apoga, R.R. (2015). Availability of Alternative Financial Resources for SMEs as a Critical Part of the Entrepreneurial EcoSystem: Latvia and Italy. Procedia Economics and Finance 33:200 - 210

Dobermann, A.., Nelson, R., Beever, D., Bergvinson, D., Crowley, E., Denning, G., Giller, K., Hughes, J., Jahn, M., dan Lynam, J. (2013). Solutions for Sustainable Agriculture and Food Systems, Technical Report for the Post-2015 Development Agenda; Thematic Group on Sustainable Agriculture and Food Systems of the Sustainable Development Solutions Network, Food Systems Development (Center for Transformative Action). Inc, New York USA.

Doronina, I., Borobov, V.N., Ivanova, E., Gorynya, E dan Zhukov, B. (2016). Agro-industrial Clusters as a Factor of Increasing Competitiveness of the Region. International Journal of Economic and Financial 6(S1):295299

Haddoud, M, Y., Beynon, M.J. \& Newbery, R. (2017). "SME's" Export Propensity In North Afri.ca: A Fuzzy C-Means Cluster Analysis. Journal of Small Business and Enterprise Development.

Haynes, M. C., Ryan, N., Saleh, M., Winkel, A. F., \& Ades, V. (2017). Contraceptive Knowledge Assessment: Validity and Reliability of a Novel Contraceptive Research Tool. Contraception 95, 190-197.

Hrezat, R. S \& Abdalkarim, G.M. (2013). The Role of Packaging in Consumer's Perception of Product Quality at the Point of Purchase.
European Journal of Business and Management 5 (4).

Hurley, R \& Hult, G. T. (1998). Innovation, Market Orientation and Organizational Learning: An In tegration and Empirical Exemination. Journal of Marketing, 62 (3), 42-54.

Isbasoiu, G. M. (2007). Industrial Clusters And Regional Development: The Case of Timisoara And Montebelluna, MPRA Paper No. 5037, 3. (Access Date 05.05.2013, http://mpra.ub.uni muenchen.de/5037/).

Kinyajui, C., Misigah, G \& Ohaya, O. (2013). One Village One Product (OVOP) - Regional Sustainable Development in Kenya. International Journal of Science and Research (IJSR) 2319-7064.

Kumoro, A.C., Amalia, R.., Retnowati, D., Budiyati, C \& Ratnawati, R. (2014). Preparation And Physicochemical Characterization of Modified (Acetylated) Gadung (Dioscorea Hispida Dennst) Flours. Scientific Study \& Research Chemistry \& Chemical Engineering, Biotechnology, Food Industry Cicbia 15 (2).

Liu, R., Weng, Q., Mao, G \& Huang, T. (2016). Industrial cluster, government agency and entrepreneurial development. Chinese Management Studies 7( 2), 253-280.

Maduekwe, C.C. \& Kamala, P. (2016). Performance Measurement by SMEs in Cape Metropolis South Africa. Journal Problem and Perspective in management $14(2)$.

Marique, T., Mery, D \& Pedreschi, F. (2007). Quality Evaluation and Control of Potato Chips and French Fries. Computer Vision Technology For Food Quality Evaluation. Santiago. Chilli ISBN: 978-0-12-373642-0.

Martina \& Asrina. (2017). Strategi Pemasaran Usaha Kerupuk Tempe Di Desa Blang Geulanggang Kecamatan Peusangan Kabupaten Bireuen (Studi Kasus:Usaha Kerupuk Tempe Ibu Yusnita). Jurnal S. Pertanian 1 (1), 48 - 62.

Mentzer, J.T., Dewitt, W., Kkebler, J., Min, S., Nix, N.W., Smith, C.D., \& Zacharia, Z.G. (2001). Defining Supply Chain Management. Journal Of Business Logistics 22 (2), 1-25.

Mikhailov, L dan Tsvetinov, P. (2004). Evaluation of Services Using a Fuzzy AHP. Applied Soft Computing Journal Vol. 5 No.1 pp: 23-33

Nad, I., Adelsberger, Z dan Buntak, K. (2012). Impact of Product Quality In The Business of The Organization. International Journal for Quality research 6(3).

Nguyen Thi, A. T. (2013). One Village One Product (OVOP) in Japan to One Tambo One Product (OTOP) in Thailand: Lessons for Grass Root Development in Developing Countries. Journal of Social and Development Sciences 4(12), 529-537. 
Omole, 0 \& Omolayo, B. (2013). Influence of Mental Workload on Job Performance. International Journal of Humanities and Social Science. 3 (15).

Porter M. (1998). Cluster and new economics of competition, Harvard Business Review, issue from november-december 1998. Available at: https://hbr.org/1998/11/clusters-and-thenew-economics-of-competition

Rijanto, E. (2017). Laporan Kajian Arah Pengembangan Klaster Nasional Dalam Rangka Mendukung Pengendalian Inflasi. Jakarta. Bank Indonesia.

Schumann, R. F. (2016). A Study of One Village One Product (OVOP) and Workforce Development: Lessons for Engaging Rural Communities around the World. University of Guam. Japan.

Siahaan, S. (2016). Analisis Klaster Industri Dalam Perspektif Manajemen Rantai Pasokan Perkebunan Kelapa Sawit Di Provinsi Sumatera Utara. Jurnal Ekonomi \& Kebijakan Publik 7(2), $201-213$.

Sigih, M.N. (2007). Strategi Penguatan Usaha Mikro Kecil Menengah (UMKM) Sebagai Refleksi Pembelajaran Krisis Ekonomi Indonesia. Jurnal Ekonomi MODERNISASI 3(3):218-227.

Sugiarto, D., Ma'arif, M.S, Sukardi dan Honngokusumo, S. (2010). Selection of Industru Cluster Development Strategy and Knowledge Management Strategy at Latex Dipped Goods Industrial Cluster. Jurnal Teknologi Industri Pertanian 20(2):89-100.

Syafitri, D.U., Sukmawati, A dan Muslim, M, I. (2017). Implementasi Organisasi Pembelajar bai Keberlanjutan UKM Klaster Kerajinan Batik di Cirebon. Jurnal Manajemen Teknologi 16(3), 294-309.

Tödtling, F \& Trippl, M. (2008). Cluster renewal in old industrial regions: Continuity or radical change in Karlsson, C. (ed.), Handbook of Research on Cluster Theory, Cheltenham, Edward Elgar.

Zainuddin, Z. (2018). Peran Peningkatan Pengembangan UMKM melalui Pemasaran. Jurnal Konsep Bisnis dan Manajemen 5(1) 1-8.

Zucchella, A. \& Siano, A. (2014). Internationalization and Innovation as Resources For SME Growth In Foreign Markets: A Focus On Textile And Clothing Firms In The Campania Region. International Studies of Management \& Organization 44(1), 21-41. 